\title{
Irena Szewczyk-Kowalewska
}

Uniwersytet Łódzki

\section{$Z$ rozważań nad edukacja kulturalną dziecka na lamach periodyku „Edukacja i Dialog” w latach dziewięćdziesiątych XX wieku}

Rozważania nad edukacją kulturalną w Polsce w latach dziewięćdziesiątych XX wieku wpisują się $\mathrm{w}$ obszerny dyskurs dotyczący przemian zachodzących w naszym kraju po 1989 r. Lektura czasopisma „Edukacja i Dialog” potwierdza tę obserwację. Miesięcznik powstały w roku 1985 jako pismo środowiska oświaty niezależnej, w latach dziewięćdziesiątych prezentował na swoich łamach - podobnie jak obecnie - artykuły z zakresu pedagogiki, psychologii, socjologii społecznej i szeroko pojętej edukacji kulturalnej. W artykułach, oprócz omówień innowacji z dziedziny metodyki dydaktyczno-wychowawczej w kraju i za granicą (co warto podkreślić), pojawiały się głosy komentujące zanik obowiązujących dotąd standardów (jak nauczanie muzyki w szkołach średnich) oraz wyrażające nadzieje i obawy związane z gwałtownym rozwojem mediów (w szczególności telewizji i reklam) oraz nowych technologii (m. in. gry komputerowe, początki intensywnego korzystania z internetu).

Uważna lektura artykułów dotyczących edukacji kulturalnej pozwala dostrzec proces głębokich zmian zachodzących w polskiej edukacji. Teksty pisane niejako „na bieżąco" były wyrazem dużej otwartości autorów, ich zaangażowania oraz nowoczesnego podejścia do oświaty i wychowania. Stanowiły cenne źródło inspiracji, były jedną z niewielu wówczas sposobności do wyrażania własnych opinii, prezentowania badań, dzielenia się osiągnięciami, korzystania $\mathrm{z}$ doświadczeń innych. Obecnie zaś owe artykuły, poza wymienionymi walorami, mają jeszcze jeden, niezwykle istotny i jakże cenny - są ,śswiadectwem czasu”, dzięki któremu możemy spojrzeć z szerszej perspektywy na zmiany w edukacji kulturalnej i wyciagnąć wnioski $\mathrm{z}$ tej swoistej lekcji historii, porównując ówczesne dokonania i porażki z tym, co aktualnie dzieje się na gruncie edukacji.

Znaczącym obrazem zachodzących przemian jest fakt, że omawiane czasopismo oprócz wersji tradycyjnej, ma dziś także swój odpowiednik elektroniczny, a „Edukacja i Dialog” oznacza nie tylko drukowany miesięcznik, ale również wirtualną ,platformę do wymiany poglądów i informacji o współczesnej edukacji” - jak czytamy na stronie internetowej www.eid.edu.pl. 
Ze względu na olbrzymią różnorodność prezentowanych artykułów należy je w określony sposób uporządkować, aby móc przybliżyć te najbardziej interesujące. Jednym ze sposobów, by tego dokonać, może być wskazanie najczęściej poruszanych tematów. Znalazły się wśród nich wątki związane z rolą muzyki w kształtowaniu wrażliwości i wyobraźni dziecka. Autorzy artykułów koncentrowali się także na zadaniach literatury, teatru i filmu $\mathrm{w}$ procesie edukacji. Dużą grupę stanowiły tematy powiązane z oddziaływaniem telewizji, reklam i gier komputerowych na psychikę oraz rozwój dziecka. Sporo miejsca zajęły artykuły prezentujące wyniki przeprowadzonych procedur badawczych dotyczących np. upodobań filmowych dzieci i młodzieży czy porównania stanu faktycznego i wyobrażeń na temat szczęśliwego dzieciństwa. Pojawiły się również wypowiedzi będące albo zapisem doświadczeń edukacyjno-pedagogicznych, albo konkretnymi propozycjami prowadzenia zajęć, np. z wykorzystaniem wideo, komputera lub możliwości płynących z niestandardowego podejścia do pracy z dziećmi.

Już tylko ta pobieżna próba klasyfikacji poszczególnych artykułów uzmysławia, że jest to dość karkołomne zadanie. Dlatego pozwoliłam sobie na wprowadzenie znacznie prostszej ,zasady porządkującej”. Najbardziej oczywisty wydał się podział na „tradycję” i „nowoczesność”. Wiąże się to także ze specyfiką lat 90. i nieodłącznie wpisanym w ten okres dynamicznym rozwojem nowych technologii, pojawieniem się nieznanych wcześniej zawodów i postępującą elektroniczną rewolucją, niosąca zasadniczą zmianę kulturową ${ }^{1}$. Przyjęcie takiego kryterium podziału było więc czymś naturalnym, umożliwiło wyodrębnienie tematów zogniskowanych wokół znanych i od dawna obecnych elementów edukacji kulturalnej (takich jak muzyka, literatura, teatr, prasa) oraz będących próbą oswojenia i zbadania nowych zjawisk (film, wideo, telewizja, reklama, gry komputerowe). Osobną kategorię, przy tak nadanym porządku, stanowią artykuły o charakterze bardziej teoretycznym, zgrupowane przeze mnie i opatrzone wspólnym hasłem „Edukacja kulturalna - konteksty i propozycje”2.

${ }^{1}$ Zob. A. Franaszek, W wieku Chrystusowym. Rozmowa z Pawłem Śpiewakiem, „Tygodnik Powszechny Online", http://www.tygodnik.com.pl/kontrapunkt/63/spiewak.html.

${ }^{2}$ Do wyżej wymienionej kategorii należą następujące artykuły (w porządku chronologicznym): A. Kołakowski, Literacki stereotyp kultury polskiej, „Edukacja i Dialog [dalej: EiD]”, kwiecień 1994, http://www.eid.edu.pl/archiwum/1994,24/kwiecien,28/; G. Jańczyk, Edukacja kulturalna to nie tylko teatr $i$ film, EiD, październik 1994, http://www.eid.edu.pl/archiwum/1994,24/padziernik,32/; J. Krasicki, W kulturze nie ma dróg na skróty, EiD, styczeń 1995, http://www.eid.edu.pl/archiwum/1995,93/styczen,105/; A. Cudowska, Dialog kultur, EiD, grudzień 1995, http://www.eid.edu.pl/archiwum/1995,93/grudzien,114/; A. Żywczok, Wychowanie do życia wartościowego, EiD, marzec 1997, http://www.eid.edu.pl/archiwum/1997,95/marzec,127/; D. Allen, Kultura szkoły społecznej, EiD, czerwiec 1997, http://www.eid.edu.pl/archiwum/ 1997,95/czerwiec,130/; A. Barska, Ksztattowanie kultury estetycznej; D. Konatkiewicz, Przysposobienie do twórczości, EiD, grudzień 1997, http://www.eid.edu.pl/archiwum/1997,95/ grudzien,134/; E. Arciszewska, Kto powie, co dobre, a co złe?, EiD, luty 2000, http://www.eid. edu.pl/archiwum/2000,98/luty,156/ 
To dość liczna i różnorodna grupa, w której albo są odniesienia zarówno do tradycyjnych, jak i nowoczesnych elementów edukacji, albo nie ma do nich żadnych bezpośrednich odwołań.

W pierwszym nurcie, czyli szeroko pojętej „tradycji”, znalazły się m. in. artykuły traktujące o muzyce ${ }^{3}$. W większości są one głosem nauczycieli-praktyków i pedagogów-teoretyków podkreślających ogromną rolę muzyki w formowaniu osobowości i wrażliwości dziecka, a także muzyki traktowanej jako „element kształtujący poglądy wobec różnych zjawisk kulturowych i rozwijający wrażliwość estetyczną przyszłego społeczeństwa" ". Na ogół prezentowane teksty mają charakter teoretycznej refleksji, wyjątek stanowią artykuły Mirosława Brzany, który przedstawia w nich $\mathrm{m}$. in. swoje - jak pisze -

[...] próby wielostronnego wykorzystywania zajęć muzycznych do przełamywania granic między ludźmi oraz między przedmiotami nauczania (formami aktywności uczniowskiej). Punktem wyjścia do poszukiwania opisanych ćwiczeń i zabaw było przeświadczenie, że: człowiek jako istota społeczna, dążąca do życia w grupie, powinien doskonalić umiejętność wyrażania siebie oraz odbierania komunikatu z zewnątrz. Im różnorodniejszymi środkami wyrazu będzie dysponował, tym chętniej będzie wchodził $\mathrm{w}$ interakcje społeczne, dzięki czemu będzie szczę́liwszy i zdrowszy. Muzyka jako specyficzny język pozawerbalny (język dźwięku i gestu) może dostarczyć nowych form ekspresji ${ }^{5}$.

W dalszej części artykułu autor podaje przykłady gier i zabaw muzycznych (m. in. zagadki baletowe, konferencja prasowa, słuchowisko, zespołowe improwizacje), które wykorzystuje w swojej pracy z dziećmi.

Pozostałe artykuły (np. Istota wartości w muzyce Adriany Barskiej, O konieczności wczesnego umuzykalniania Ewy Klimas-Kuchtowej, Edukacja bez muzyki? Joanny Jemielnik) kładą nacisk na rzetelnie prowadzoną edukację muzyczną zarówno wśród najmłodszych dzieci, jak i młodzieży.

Adriana Barska podkreśla rolę nauczyciela w procesie czynnego wychowania muzycznego najmłodszych. W swoich rozważaniach prezentuje oczywistą wydawałoby się opinię, że ,aktywna recepcja sztuki ma charakter swoistego współautorstwa"6. W kontekście szerzej pojętej edukacji kulturalnej dziecka ta

${ }^{3}$ Artykuły poświęcone bezpośrednio edukacji kulturalnej poprzez muzykę: M. Brzana, O integracyjnej roli muzyki, EiD, styczeń 1994, http://www.eid.edu.pl/archiwum/1994,24/styczen,25/; idem, Gdzie słowa zawodza, tam mówi muzyka, EiD, maj 1996, http://www.eid. edu.pl/archiwum/1996,94/maj,119//; idem, Obcowanie z muzykq, EiD, styczeń 1999, http://www. eid.edu.pl/archiwum/1999,97/styczen,145/; A. Barska, Istota wartości w muzyce, EiD, maj 1996, http://www.eid.edu.pl/archiwum/1996,94/maj,119/; E. Klimas-Kuchtowa, O konieczności wczesnego umuzykalniania, EiD, luty 1999, http://www.eid.edu.pl/archiwum/1999,97/luty,146/; J. Jemielnik, Edukacja bez muzyki?, EiD, styczeń 2000, http://www.eid.edu.pl/archiwum/ 2000,98/styczen,155/

${ }^{4}$ J. Jemielnik, Edukacja...

${ }^{5} \mathrm{M}$. Brzana, O integracyjnej roli...

${ }^{6} \mathrm{~A}$. Barska, Istota wartości... 
konstatacja A. Barskiej jest warta podkreślenia. Zazwyczaj bowiem edukacja kulturalna kojarzona bywa z nabywaniem kompetencji kulturowych, charakteryzujących się „teoretycznym” przygotowaniem do odbioru dóbr kultury. Tymczasem, aby owe kompetencje były pełne, niezbędne jest również praktyczne zaangażowanie. Dlatego, jak zauważa A. Barska, niezwykle istotną rolę w tym procesie odgrywa nauczyciel.

Kierowanie procesem tworzenia jest [bowiem] zadaniem trudnym, wymagającym w pierwszym rzędzie twórczej postawy samego nauczyciela. W pełni sprawdzić się on może wtedy, gdy posiada nie tylko zdolności twórcze, lecz także wiadomości z zakresu estetyki, psychologii rozwojowej, psychologii muzyki, znajomość podstaw kompozycji, a nadto - zdolność inspirowania, wyzwalania w dzieciach ich ukrytych nieraz zdolności, wyobraźni, fantazji, ujawniania nie zawsze uświadamianych emocji ${ }^{7}$.

Autorka artykułu ma wprawdzie na myśli nauczyciela muzyki, ale jej słowa można odnieść także do innych dydaktyków. Z pewnością taka postawa nauczycieli i tak pomyślany program edukacji kulturalnej, czy to przez muzykę, czy inny rodzaj sztuki, byłby wariantem optymalnym, przynoszącym wymierne efekty i dostrzegalnym w życiu społecznym poprzez zmianę postaw i upodobań.

Niejako uzupełnieniem poruszanych dotąd kwestii mogą być przemyślenia Ewy Klimas-Kuchtowej oraz Joanny Jemielnik. Pierwsza spośród wymienionych, podsumowując swoje rozważania, pisze:

[...] trzeba z całą mocą podkreślić, że pełny sposób korzystania z potężnej siły muzyki wymaga wejścia w muzyczny świat oddziaływań, a wejście to powinno być ułatwione każdemu, i to tak wcześnie, jak tylko jest to możliwe. Z pewnością warto zintensyfikować wysiłki zmierzające w tym celu ${ }^{8}$.

Z kolei refleksja J. Jemielnik dotyka ważnej kwestii zniesienia obligatoryjności muzyki w starszych klasach szkoły podstawowej, gimnazjum i liceum. Konsekwencją tego kroku jest m. in. fakt, że

Poza wąską grupą specjalistów i muzyków zawodowych znikoma część społeczeństwa orientuje się w dorobku polskiej kultury muzycznej i aktywnie uczestniczy w imprezach artystycznych. Przeciętny słuchacz nie zawsze umie prawidłowo ocenić wartość estetyczną różnych gatunków muzyki. Przeważająca część społeczeństwa, nawet wywodząca się ze sfer z wyższym wykształceniem, traktuje kulturę muzyczną jako czynnik dostarczający jedynie rozrywki i relaksu, przy czym coraz rzadsza jest chęć obcowania ze sztuką profesjonalną wysokiego lotu'.

Ponadto lekceważenie rangi wychowania poprzez sztukę i wychowania „do sztuki” sprawia, że w ogromnym stopniu zostaje ograniczone świadome uczest-

\footnotetext{
${ }^{7}$ Ibidem.

${ }^{8}$ E. Klimas-Kuchtowa, O konieczności...

${ }^{9}$ J. Jemielnik, Edukacja...
} 
nictwo nie tylko - jak podaje autorka - w kulturze muzycznej wysokiego lotu, ale również w kulturze teatralnej czy filmowej - słowem każdej, która wymaga większego wysiłku i zaangażowania zarówno sfery intelektualnej, jak i emocjonalnej oraz duchowej.

Stąd też w konkluzji J. Jemielnik czytamy:

[...] trzeba pamiętać, że najważniejszym zadaniem jest integralny rozwój wszystkich sfer osobowości ucznia. Obok kształcenia sprawności intelektualnych w większym niż dotychczas stopniu należy zwrócić uwagę na potrzebę rozwoju duchowego, kształtowanie wrażliwości i poczucia piękna. To wartości $\mathrm{w}$ istotny sposób wspomagające umiejętność kierowania emocjami, rozwojem moralnym, a nawet fizycznym. Uświadomienie tego faktu powinno pomóc w lepszym zrozumieniu znaczenia przedmiotów artystycznych i podniesieniu ich rangi zarówno w edukacji szkolnej, jak i w świadomości całego społeczeństwa ${ }^{10}$.

W podobnej tonacji utrzymane są także pozostałe artykuły umieszczone w nurcie umownie przeze mnie nazwanym „tradycją". Co ciekawe, najbardziej „popularny”, jak można by sądzić, w owej grupie tematycznej teatr nie doczekał się w omawianym okresie na łamach „Edukacji i Dialogu” większej liczby artykułów niż literatura czy muzyka ${ }^{11}$. Wśród zaprezentowanych tekstów jeden jest pełnym pasji opisem działań edukacyjnych nauczycielki z Liceum Ogólnokształcącego w Kętrzynie, Stanisławy Łozińskiej, drugi zaś stanowi naukowo ujętą, spójną wizję edukacji teatralnej, zaproponowaną przez Wiesława Żardeckiego z Uniwersytetu Marii Curie-Skłodowskiej w Lublinie.

Słowa S. Łozińskiej pokazują optymistyczną, nieco może przypominającą pozytywistyczną ideę ,pracy u podstaw”, wizję konkretnego i konsekwentnego realizowania edukacji przez teatr nie tylko w ramach zajęć szkolnych, ale przede wszystkim pozaszkolnych.

\section{S. Łozińska pisze:}

Do odbioru sztuk trudnych jesteśmy zawsze przygotowani. Czasem informacji szukają uczniowie, czasem przekazuję je sama. Staram się nie mówić dużo, tylko to, co potrzebne, czego uczeń jeszcze nie wie, a co jest konieczne do zrozumienia dzieła. Może to być geneza dramatu, autentyczność postaci, konwencja literacka, obowiązująca w okresie powstawania utworu istota trudniejszego gatunku, np. teatru absurdu, filozofia autora itp.

Każdy wspólnie oglądany spektakl musi być przedyskutowany. Zwykle robimy to zaraz po wyjściu z teatru, potem w dworcowej poczekalni i już w mniejszych grupach w pociagu. Każdy musi powiedzieć to, co myśli i zawsze do tego prowokuję. Spory są mile widziane, bo i tak w końcu jakoś się godzimy i nawet nie zawsze ja występuję w roli arbitra. Cieszę się, kiedy sztuka zrobiła wrażenie, zaintrygowała, wzruszyła siłą wymowy, kiedy uczniowie zapisuja jakieś sentencje, żeby nie zapomnieć, a najbardziej wtedy, kiedy dostrzegli to, co ja przeoczyłam ${ }^{12}$.

${ }^{10}$ Ibidem.

11 S. Łozińska, Edukacja przez teatr, EiD, czerwiec 1994, http://www.eid.edu.pl/archiwum/ 1994,24/czerwiec,30/; W. Żardecki, Edukacja teatralna, EiD, grudzień 1997, http://www.eid. edu.pl/archiwum/1997,95/grudzien,134/.

${ }^{12}$ S. Łozińska, Edukacja... 
Zupełnie inny charakter ma artykuł W. Żardeckiego. Tu nacisk jest położony na precyzyjne wyjaśnienie pojęć i przedstawienie całościowego obrazu edukacji poprzez teatr. Autor wskazuje m. in. trzy zasadnicze i równoległe kierunki działania, warunkujące realizację edukacji teatralnej. Są to:

- utrzymywanie bezpośredniego kontaktu $\mathrm{z}$ teatrem, a więc oglądanie przedstawień teatralnych;

- analizowanie i interpretowanie utworów dramatycznych w ścisłym związku z realizacjami teatralnymi;

- zachęcanie i zjednywanie, inicjowanie i stymulowanie ekspresji teatralnej uczniów ${ }^{13}$.

Aby te działania mogły przynieść oczekiwane efekty, czyli przyczynić się do wykształcenia

[...] wszechstronnej osobowości ucznia o postawie otwartej, świadomego swej przeszłości (tradycji), a także wymogów teraźniejszości i przyszłości, niewątpliwie ważnym elementem tego rodzaju edukacji będzie kształcenie historyczne. Najważniejszą jednak sprawą w procesie edukacji jest sztuka interpretacji spektaklu teatralnego, pozwalająca ujawnić funkcjonowanie poszczególnych warstw, elementów i aspektów tegoż spektaklu w związku z jego koncepcją ideowo-artystyczna, a przez to ukazać go jako dzieło sztuki o otwartym odbiorze, w myśl przekonania o współtwórczej roli widza.

Podsumowując swoje rozważania, W. Żardecki wybiega myślą poza teatr i odnosi koncepcje edukacji także do innych dziedzin sztuki, aby poprzez tak szeroko zakrojone działania oświatowe wykształcić w przyszłości w społeczeństwie nowe postawy uczestnictwa w życiu kulturalnym. Teatr ma na tym polu do zrealizowania szczególne zadanie, ponieważ - jak podkreśla autor -

[...] bardziej niż jakakolwiek inna sztuka urzeczywistnia modele estetyczne, artystyczne czy szerzej - ogólnokulturowe oraz inspiruje artystyczne i światopoglądowe trendy (wizje przyszłości kultury); wykrywa (niby radar) podstawowe antynomie egzystencji ludzkiej i konkretnego czasu historycznego (wszystko to, co wskazuje na potrzebę modyfikacji); wymusza niejako postawę pytającą względem siebie i otaczającego świata $\mathrm{i}$ to zarówno w sensie ich afirmacji, jak też krytycznej analizy ${ }^{14}$.

Znaczącą rolę edukacyjną autorzy artykułów umieszczonych na łamach „Edukacji i Dialogu” wyznaczyli także literaturze, prasie dziecięcej i baśniom. Literatura pojawia się w szczególnym kontekście - a mianowicie filmowych realizacji kanonu lektur szkolnych ${ }^{15}$. Ze względu na to specyficzne ujęcie

${ }^{13}$ W. Żardecki, Edukacja...

${ }^{14}$ Ibidem.

${ }^{15}$ M. Sokołowski, Młodzież wobec filmowych adaptacji literatury, EiD, styczeń 1995; http://www.eid.edu.pl/archiwum/1995,93/styczen,105/; idem, Ksiażka czy film. Klasyka literacka $w$ odbiorze audiowizualnym, EiD, marzec 1995; http://www.eid.edu.pl/archiwum/1995,93/ marzec,107/; idem, Upodobania filmowe najmłodszych, EiD, czerwiec 1995, http://www.eid. edu.pl/archiwum/1995,93/czerwiec,110/. 
chciałabym omówić tę grupę artykułów nieco później, traktując je jako swoisty pomost między „tradycją” a „nowoczesnością”.

Natomiast godne uwagi wydają się propozycje dotyczące wykorzystania w procesie edukacji prasy dziecięcej. Danuta Żebrowska z Uniwersytetu Gdańskiego w swoim artykule stwierdza następująco: „Współczesne polskie czasopiśmiennictwo dziecięce należy do najbardziej rozwiniętych w Europie; jest ono adresowane do czterech poziomów rozwojowych, dostosowując do ich możliwości percepcyjnych i zainteresowań treść oraz formę edytorską" ${ }^{\prime 16}$.

Autorka krótko omawia czasopisma przeznaczone dla uczniów klas I-III. Wymienia przede wszystkim dwa tytuły: „Gazeta Dzieci” oraz „Wzorce”, nawiązuje także do „Świerszczyka”, jednego z najstarszych pism dla dzieci. Pisząc o roli prasy dziecięcej, zwraca uwagę na kilka istotnych kwestii, m. in., że

[...] Świat w czasopismach dziecięcych i proponowany system wartości jest zbudowany z elementów bliskich rzeczywistości i wyobraźni dziecięcej. Wszystko rozgrywa się (poza baśniami, legendami) tu i teraz. Funkcja dydaktyczna jest (na ogół) podporządkowana funkcji estetycznej; przesłanie moralne (w sposób naturalny) wynika z przedstawionej sytuacji. Szczególnie baśnie prezentują w sposób zrozumiały dla dzieci problemy dobra i zła; znajduje w nich wyraz głęboko ludzka potrzeba sprawiedliwości - dobro powinno być bezwzględnie wynagrodzone, a zło ukarane ${ }^{17}$.

Propagowane przez D. Żebrowską magazyny dziecięce to te najbardziej wartościowe, jednakże warto przy okazji tego artykułu zastanowić się, czy te czasopisma były i są chętnie czytane przez same dzieci. Codzienne doświadczenie zarówno z lat 90., jak i dzisiejsze zdaje się pokazywać nieco odmienne upodobania najmłodszych. Ponadto rynek czytelniczy w ciagu ostatnich 20 lat bardzo się zmienił. Liczba tytułów wzrosła kilkakrotnie. Wybór jest ogromny, tym większa zatem rola rodziców i pedagogów, aby nie tylko potrafili wskazać najwartościowsze czasopisma, ale także przekonać dzieci i młodzież do ich czytania, zwłaszcza że, jak podkreśla autorka artykułu,

Prasa obok telewizji, radia oraz filmu jest zaliczana do środków masowej komunikacji. Stanowi ona niezbędne źródło uzyskiwania różnorodnych aktualnych informacji o życiu w kraju i na świecie, jest jednym $z$ instrumentów wychowania i naturalnych dróg socjalizacji oraz ważną pomocą dydaktyczna. Pełni trzy podstawowe funkcje: informacyjną, wychowawczą i rozrywkową ${ }^{18}$.

${ }^{16}$ D. Żebrowska, Wychowawcza rola prasy dziecięcej, EiD, wrzesień 1997, http://www. eid.edu.pl/archiwum/1997,95/wrzesien,131/wychowawcza_rola_prasy_dzieciecej,620.html.

${ }^{17}$ Ibidem.

${ }^{18}$ Ibidem. Dla zilustrowania obecnego bogactwa rynku prasowego dla dzieci i młodzieży, wymienię tylko kilka najbardziej popularnych czasopism. Są wśród nich czasopisma tematycznohobbystyczne (np. „Przyroda Polska”, „Kraina Zwierząt”, „PSX Extreme” - magazyn poświecony grom video), są dla najmłodszych czasopisma, których bohaterami są znane postacie z bajek i kreskówek (np. „Scooby-Doo”, „Strażak Sam”, „Świat przygód z Hugo”, „Tom i Jerry”), są wreszcie pisma dla nastolatków, takie jak „Dziewczyna”, ,Joy”, czy „Bravo”. Ponadto sporo pism tematycznych, poświeconych komputerem, grom strategicznym i fabularnym, historii. 
Wokół problemu czytelnictwa, a właściwie lepiej byłoby powiedzieć, że u jego podstaw, koncentruje swoją wypowiedź Barbara Murawska ${ }^{19}$. Podejmuje ona temat roli czytanek w nauczaniu początkowym. Autorka sceptycznie podchodzi do schematu nauki czytania, uważając go za mało twórczy, a przez to również mało efektywny. Opisuje go następująco:

Lekcję rozpoczyna wprowadzenie tzw. wyrazu podstawowego, z którego następnie wyodrębnia się opracowywaną danego dnia głoskę i literę. Tu występuje analiza i synteza słuchowa i wzrokowa wyrazu podstawowego. Następnie zwykle się pojawiają przykłady innych wyrazów, w których występuje nowa głoska. Kolejny etap to poznawanie kształtu litery i jej pisanie w ćwiczeniach i w zeszycie. Nauczyciel, w mniejszym bądź większym stopniu, trzyma się tego toku postępowania w trakcie wprowadzania wszystkich liter. Prowadzi to do pewnego schematyzmu w uczestniczeniu dzieci w lekcji, który każe w większym stopniu zwracać uwagę na to, jak się robi, niż na to, co się robi. Uczniowie szybko się uczą, w którym momencie trzeba wyjąć ćwiczenia, otworzyć elementarz czy przygotować nożyczki i klej. Więcej uwagi przywiązują do schematu czynności, niż do pracy intelektualnej ${ }^{20}$.

Zadając przewrotne, jak się okazuje w kontekście całego tekstu, pytanie o wyrzucanie czytanek, w istocie pyta o sens opisanego powyżej schematu nauki czytania, wyrabiania pewnych czytelniczych nawyków, które później są przenoszone na samodzielne kontakty z literaturą. Tym, co, zdaniem autorki, powinno być podstawą przy poznawaniu liter, jest budzenie autentycznej potrzeby czytania u najmłodszych. Niestety tego ostatniego elementu bardzo często w szkołach brakuje - ważniejsze okazują się programy nauczania i porządek na lekcji. Mimo to B. Murawska z dużym przekonaniem pisze:

[...] nic nie wspomaga tak czytania jak indywidualna, autentyczna potrzeba wglądu w tekst pisany. Ta autentyczna potrzeba oznacza dla każdego dziecka coś innego. Pewien ośmiolatek nauczył się czytać dopiero wtedy, gdy zapragnął samodzielnie poznać żarty o Masztalskim. Pokazuje to, że szkoła, zaniedbując motywowanie uczniów do nauki czytania, może się czuć usprawiedliwiona. Trudno przewidzieć indywidualne potrzeby ucznia. Można natomiast tak organizować pracę z tekstem, by istniała konieczność samodzielnego poznawania jego zawartości, a nie czytania tylko dla ćwiczenia sprawności w odtwarzaniu fonetycznym. Wiąże się z tym zapewne rodzaj tekstów, z którymi uczniowie mają kontakt w szkole. Często są to tylko nudne czytanki bądź pozbawione związku $\mathrm{z}$ doświadczeniami dzieci lektury szkolne ${ }^{21}$.

Swego rodzaju kontynuacją tematu niskiej efektywności szkoły wobec wyzwań edukacyjnych są refleksje Andrzeja Kołakowskiego z Uniwersytetu Warszawskiego, który wychodząc od rozważań nad utrwalonym powszechnie „literackim stereotypem kultury polskiej”, pisze o konieczności spójnego i usystematyzowanego przekazywania wiedzy o kulturze narodowej ${ }^{22}$. Strzępki infor-

${ }^{19}$ B. Murawska, Czy wyrzucić czytanki?, EiD, marzec 1998, http://www.eid.edu.pl/archiwum/1998,96/marzec,137/czy_wyrzucic_czytanki,700.html.

${ }^{20}$ Ibidem.

${ }^{21}$ Ibidem.

${ }^{22}$ A. Kołakowski, Literacki stereotyp... 
macji zdobywane najczęściej na lekcjach języka polskiego nie odpowiadają potrzebom budowania prawdziwego obrazu kultury polskiej. Autor podkreśla jednak realność swoich oczekiwań i nie żąda gwałtownej reformy całego systemu oświaty, a jedynie apeluje o

[...] tworzenie atmosfery intelektualnej, ukierunkowywanie badań i procesów kształcenia w strukturach istniejących w naszej nauce i uczelniach, o inspirowanie prac naukowych, dyplomowych, popularyzatorskich, o publikowanie źródeł wiedzy o dziejach naszej kultury, o wprowadzanie autorskich programów do szkół - a więc o szeroki i długotrwały wysiłek badawczy, wydawniczy, nauczycielski. Idzie mi o proces racjonalizacji wiedzy o kulturze polskiej jako swoistej całości i przezwyciężanie w ten sposób mitu o jej literackim charakterze ${ }^{23}$.

Warto zastanowić się, na ile ów postulat udało się zrealizować. Na pewno widoczny jest postęp w budowaniu bliższego realiom obrazu kultury polskiej, wiele stereotypów uległo rozproszeniu. Zmienił się - wielokrotnie - kanon lektur szkolnych, dzieła dawnych mistrzów straciły zaś nieco ze swej mocy kształtowania narodowej wyobraźni. Dziś zastępują je środki masowego przekazu, a kreowane przez nie wizerunki stanowią przedmiot troski badaczy. Literatura zyskała nowe miejsce w edukacji kulturalnej - przestała być wyznacznikiem „wartości narodowych”, jej rola i oczekiwania wobec niej zaczęły się zmieniać.

W zupełnie innym tonie utrzymane są rozważania pośrednio tylko poświęcone literaturze, ale mieszczące się w nurcie „tradycji” i zawarte w artykule przywoływanej już S. Łozińskiej ${ }^{24}$. Tym razem opisuje ona swoje doświadczenia związane z przekazywaniem wiedzy dotyczącej rozumienia wyrazów obcych, haseł, przysłów w sprawnym i poprawnym posługiwaniu się polszczyzną. Opisywane przez autorkę metody i efekty, które dzięki nim uzyskuje, nie pozwalają na pogrążenie się w poczuciu klęski po schematycznej i nietwórczej nauce czytania, czy nieskutecznej edukacji w dziedzinie kultury narodowej.

Swego rodzaju odskocznią od dotąd poruszanych tematów mogą być dwa interesujące artykuły poświęcone baśniom ${ }^{25}$. Autorki obu tekstów, Franciszka Dyka, pisząca o roli bajek w edukacji początkowej, oraz Anna Piotrowska, podkreślająca baśniowy charakter widowisk muzycznych, odwołują się do wyjątkowej siły oddziaływania baśni i bajek oraz wspominają o ich niebagatelnym pozytywnym wpływie na rozwój wyobraźni i wrażliwości dziecka. Zarówno baśnie, jak i bajki obie autorki uważają za niezbędny i niezastąpiony element edukacji kulturalnej. Zwłaszcza teatralne lub teatralno-muzyczne inscenizacje baśni niezwykle silnie oddziałują na najmłodszych.

${ }^{23}$ Ibidem.

${ }^{24}$ S. Łozińska, Zrozumieć słowo, EiD, kwiecień 1997, http://www.eid.edu.pl/archiwum/ 1997,95/kwiecien,128/zrozumiec_slowo,573.html.

${ }^{25}$ F. Dyka, Bajki w edukacji poczatkowej, A. Piotrowska, Baśniowość widowisk muzycznych, EiD, czerwiec 1999, http://www.eid.edu.pl/archiwum/1999,97/czerwiec,150/. 


\section{F. Dyka pisze:}

Bajka przedstawiona dziecku za pośrednictwem teatrzyku zwiększa możliwości ekspresji, a zatem i siła oddziaływania na dziecko jest duża. Piękno postawy etycznej bohaterów bajki może być znacznie wzmocnione ich wyglądem zewnętrznym, pięknem wypowiadanych słów, bogatą scenerią. Jest to równocześnie wychowywanie dziecka do życia społeczno-moralnego, jak też rozwijanie jego doznań estetycznych ${ }^{26}$.

Artykuły poświęcone baśniom - pośrednio związane z literaturą i muzyką stanowiły odrębny wątek w rozważaniach na temat edukacji kulturalnej dziecka. Przywołanie ich miało na celu pokazanie olbrzymiej różnorodności propozycji edukacyjnych umieszczanych na łamach omawianego pisma. Wątek ów nie został jednak obszernie rozwinięty, pozostając jedynie elementem uzupełniającym bogaty pejzaż całości.

$\mathrm{Na}$ zakończenie refleksji skoncentrowanej wokół nurtu, który nazwałam „tradycją”, tak jak wspominałam wcześniej, kilka słów chciałabym poświęcić relacji literatura - film. Lapidarnie można je opisać posługując się tytułem jednego z artykułów, a mianowicie: Ksiqżka czy film. Klasyka literacka w odbiorze audiowizualnym. Autorem tekstów poświęconych tej tematyce jest Marek Sokołowski z Wyższej Szkoły Pedagogicznej w Olsztynie ${ }^{27}$.

Autor w jednym ze swoich artykułów przedstawia wyniki badań dotyczących odbioru adaptacji filmowych przez młodzież, a także jej preferencji i upodobań kinowych. $Z$ przeprowadzonych analiz wynika, że młodzi ludzie traktują film najczęściej jako źródło rozrywki, a w przypadku adaptacji - przy optymistycznym założeniu, że lektura jest im znana - punkt odniesienia między ich wyobrażeniami a filmową realizacją. Co ciekawe, młodzież „Zwraca uwagę, i tylko na tej podstawie ocenia film, na wątki i szczegóły, które jej zdaniem są najważniejsze. Pomija natomiast to, co jest w rzeczywistości w filmie najważniejsze. Młodzież przyjmuje więc postawę praktyczną"28.

Młodzi ludzie traktują film nie jako odrębne dzieło, lecz jako ,zastępczą lekturę". M. Sokołowski pisze o tym następująco:

Nader często, szczególnie obecnie, kiedy dostęp do filmu jest tak powszechny i łatwy poprzez kasety wideo, młodzież po obejrzeniu filmu nie sięga już po utwór literacki. Kontakt $\mathrm{z}$ adaptacją traktuje jako przyśpieszoną formę zapoznania się z lekturą szkolną, często $\mathrm{w}$ jej mniemaniu nudną i nie zasługującą na to, aby poświęcić jej więcej czasu niż wymaga tego kilkugodzinny seans przed telewizorem. Coraz powszechniejszy staje się sposób zaznajamiania się z lekturą szkolną jedynie za pomocą wideo, a nie żmudnego ślęczenia nad literackimi opisami przyrody zawartymi w Nad Niemnem lub rozterkami Konrada Gustawa z Dziadów Mickiewicza (film Lawa Tadeusza Konwickiego ${ }^{29}$.

\footnotetext{
${ }^{26}$ F. Dyka, Bajki w edukacji...

${ }^{27} \mathrm{M}$. Sokołowski, Młodzież wobec filmowych adaptacji...; idem, Ksiażka czy film...

${ }^{28} \mathrm{M}$. Sokołowski, Młodzież wobec filmowych adaptacji...

${ }^{29}$ Ibidem.
} 
Młodzież, jak wynika z artykułu M. Sokołowskiego, nie zastanawia się więc nad walorami artystycznymi filmu, nie jest też do tego przygotowana. Edukacja filmowa nie jest bowiem w zadowalający sposób prowadzona, nad czym należy ubolewać, ponieważ zarówno „potencjał odbiorczy” młodzieży, jak i możliwości edukacyjne filmu są ogromne. Niestety, poprzestanie na ekranizacji lektur to zdecydowanie za mało, zwłaszcza że mariaż kina z literaturą okazał się niekorzystny dla obu stron. Literatura straciła sporą część odbiorców, a film nie zyskał świadomych i zaangażowanych widzów.

Z dzisiejszej perspektywy można, niestety, dodać jeszcze, że obecnie młodzież nawet po „kanoniczne” adaptacje literatury sięga niechętnie, w większości przeznaczając swój czas na oglądanie filmów, które stanowią jedynie rozrywkę. I w tej sytuacji rola szkoły oraz nauczycieli, ale także środowiska pozaszkolnego w prowadzeniu edukacji filmowej, umiejętnego zachęcania do oglądania ambitnych dzieł jest nie do przecenienia. Często klasowe wyjścia do kina są jedyną szansą na spotkanie z kinem innym niż stricte przygodowe. Taki rodzaj kina przeważa bowiem wśród filmowych upodobań najmłodszych. Wyniki przeprowadzonej procedury badawczej, które przedstawia M. Sokołowski, potwierdzają to dobitnie. Ponadto wśród najchętniej oglądanych pozycji znalazły się jeszcze: filmy sensacyjne (41\% ankietowanych), komedie (38\%), filmy animowane (31\% uczniów), filmy science-fiction (25\%), bajki (21\%), filmy muzyczne (13\%), horrory (ogląda je 11\% respondentów). Ostanie dwa miejsca zajęły filmy dokumentalne i baśnie. Badania te wykonała Pracownia Filmowa WSP w Olsztynie. Ankiety przeprowadzono w roku 1995 w Szkole Podstawowej nr 12 w Olsztynie oraz Szkole Podstawowej w Mikołajkach.

Jednak, jak się zdaje, także dziś filmowe upodobania najmłodszych są podobne - zmieniają się tylko tytuły filmów. Dlatego po raz kolejny warto powtórzyć, to co zostało już powiedziane, a na co autor artykułów kładzie szczególny nacisk, pisząc:

Podsumowując wyniki badań jeszcze raz warto przypomnieć, iż szczególną rolę w rozwoju człowieka odgrywają jego zainteresowania i zamiłowania. Stanowią one kulturowe zaplecze każdego człowieka. Doprowadzenie wielkich, a zarazem trudnych wartości sztuki do wiadomości dzieci jest w dużej mierze zadaniem szkoły, w tym i nauczycieli. W tym celu należy zaznajamiać dzieci z językiem filmu, który daje możliwości wzbogacenia ich obszaru myślowego o nowy wymiar. Ale nie wszyscy przywykliśmy jeszcze do nowej sytuacji, stajemy często zdezorientowani wobec nowego sposobu komunikacji, takiego jak film, dzięki któremu świat zewnętrzny może przenikać do naszej świadomości bez jakiegokolwiek wstępnego przygotowania. Musimy oswoić się z tym procesem, gdyż obdarza on nas zdolnością wizualnego myślenia ${ }^{30}$.

Jednakże edukacja kulturalna to nie tylko film, o czym przekonują autorzy artykułów, które umieściłam poza dwoma głównymi nurtami: „tradycji” i „nowoczesności”, a które są zbiorem propozycji i teoretycznych rozważań poświę-

\footnotetext{
${ }^{30}$ M. Sokołowski, Upodobania filmowe...
} 
conych temu zagadnieniu. Grupa tekstów zaklasyfikowanych przeze mnie na użytek niniejszych rozważań pod hasłem „edukacja kulturalna - propozycje i konteksty” jest dość liczna i bardzo zróżnicowana ${ }^{31}$. Nie sposób szczegółowo omówić wszystkich przedstawionych koncepcji. Gdyby zaś szukać jakiegoś wspólnego mianownika, można by się posłużyć fragmentem jednej z wypowiedzi, w której autorka, Grażyna Jańczyk, wyjaśnia, czym jest edukacja kulturalna, a tym samym wskazuje kierunek, w którym podąża większość autorów publikujących swe teksty na łamach „Edukacji i Dialogu”. G. Jańczyk pisze następująco:

[...] na edukację kulturalną składa się kilka elementów powiązanych ze sobą. Rozumiem ją jako bezpośredni i częsty kontakt dziecka $\mathrm{z}$ dziełem lub innym przekazem kultury, jako własną działalność twórczą ucznia oraz jako elementarną wiedzę o zjawiskach kultury. Chodzi mi zatem o stworzenie w ramach prowadzonych zajęć takich sytuacji dydaktyczno-wychowawczych, które umożliwią dziecku bierne i czynne uczestnictwo w kulturze artystycznej i twórczości amatorskiej, a także o wyzwalanie pewnych potrzeb i nawyków kulturalnych, właściwy stosunek do bliższego i dalszego otoczenia ${ }^{32}$.

Autorzy pozostałych artykułów, wychodząc z podobnego jak G. Jańczyk, założenia, wskazują tylko kolejne obszary kultury, które warto włączyć w proces edukacji (np. filozofia, tolerancja i wielokulturowość, aktywność twórcza).

Opisywane w artykułach - które w pewien sposób łączą się z tymi przywołanymi powyżej, ale koncentrują się na kontekście socjologiczno-psychologicznym, warunkującym proces edukacji - badania, obserwacje i codzienne doświadczenia nauczycieli-pedagogów potwierdzają zasadność takiego podejścia, a jednocześnie pozwalają lepiej zrozumieć procesy kształtujące, niezależnie od działań edukacyjnych, wrażliwość, światopogląd i osobowość najmłodszych $^{33}$. Wśród najczęściej analizowanych kryteriów pojawia się - co wydaje się oczywiste - rodzina. Badaniom porównawczym poddane zostało także dzieciństwo jako najpiękniejszy i najszczęśliwszy okres w życiu. Okazało się, że wyniki

${ }^{31}$ G. Jańczyk, Edukacja kulturalna to nie tylko teatr i film; A. Kołakowski, Myślę, więc jestem. Filozofia $i$ kultura, EiD, październik 1994, http://www.eid.edu.pl/archiwum/ 1994,24/padziernik,32/; J. Krasicki, W kulturze nie ma dróg...; A. Cudowska, Dialog kultur...; M. Bartosiak-Tomusiak, Twórczość w edukacji, EiD, grudzień 1996, http://www.eid.edu.pl/archiwum/1996,94/grudzien,124/; A. Żywczok, Wychowanie do życia...; D. Allen, Kultura szkoły...; A. Barska, Kształtowanie kultury...; D. Konatkiewicz, Przysposobienie do twórczości...; E. Arciszewska, Kto powie, co dobre, a co złe?...

${ }^{32}$ G. Jańczyk, Edukacja kulturalna...

${ }^{33}$ S. Łozińska, Zamiast marsowej miny - uśmiech, EiD, marzec 1996, http://www.eid.edu. pl/archiwum/1996,94/marzec,117/zamiast_marsowej_miny___usmiech,465.html; K. Bulewicz, Szczęśliwe, kolorowe dzieciństwo, EiD, grudzień 1996, http://www.eid.edu.pl/archiwum/ 1996,94/grudzien,124/; F. Dyka, Dobre jest piękne, EiD, grudzień 1999, http://www.eid.edu.pl/ archiwum/1999,97/grudzien,154/dobre_jest_piekne,922.html; B. Szczupał, Rodzina ksztattuje osobowość dziecka, EiD, luty 2000, http://www.eid.edu.pl/archiwum/2000,98/luty,156/. 
badań przeprowadzonych w Łodzi w roku 1996 potwierdzają przypuszczenia, że mit szczęśliwego dzieciństwa jest bliski rzeczywistości. Badane dzieci, pisze autorka artykułu, Katarzyna Bulewicz,

[...] potwierdzają opinię dorosłych na temat dzieciństwa jako cudownego, radosnego i beztroskiego etapu w życiu człowieka. Etapu, który się wspomina z rozrzewnieniem, a nawet żalem, że już się nie powtórzy. Dorośli obecnie ludzie, którzy przeżyli dzieciństwo w taki właśnie sposób, dokładają wszelkich starań, aby ich dzieci w przyszłości również mogły wracać wspomnieniami do tej rajskiej krainy. Takie podejście do dzieciństwa może wynikać z faktu, iż zarówno dzieci, jak $\mathrm{i}$ ich rodzice nie pochodzą $\mathrm{z}$ rodzin patologicznych. Ale mimo tego moi mali rozmówcy zdają sobie sprawę, że nie wszystkie dzieci są szczęśliwe, chociaż powinny ${ }^{34}$.

Ogromną rolę rodziny w kształtowaniu osobowości dziecka i wprowadzaniu go w świat kultury podkreślają również badania przeprowadzone przez Wyższą Szkołę Pedagogiki Społecznej w Warszawie w roku 2000. Wynika z nich, że:

1) wykształcenie rodziców wpływa na aspiracje dotyczące kształcenia ich dzieci. Wyższym aspiracjom towarzyszy wyższe wykształcenie rodziców;

2) status ekonomiczny rodziny wpływa na aspiracje rodziców dotyczące kształcenia ich dzieci. Wyższym aspiracjom towarzyszy wyższy status ekonomiczny;

3) stan zdrowia dziecka wpływa na poziom aspiracji rodziców dotyczących edukacji ich dzieci. Wyższym aspiracjom towarzyszy dobry stan zdrowia dziecka;

4) kolejność urodzenia dziecka determinuje aspiracje edukacyjne, które maleją w zależności od liczby dzieci w rodzinie. Im więcej dzieci, tym niższe aspiracje kształceniowe;

5) większość rodziców chciałaby dla swojego dziecka zawodu cieszącego się dużym prestiżem społecznym (lekarz, prawnik, dziennikarz) ${ }^{35}$.

Z pewnością efekty badań nie są szczególnie zaskakujące, być może przeprowadzone dziś dałyby nieco inne wyniki. Niemniej włączają się one w proces budowania ścisłej współpracy pomiędzy szkołą a rodziną, ich wzajemnego wspierania i uzupełniania się w działaniach edukacyjnych. Choć wydaje się to oczywiste, w praktyce daleko jeszcze do postulowanego ideału. Zwracają na to uwagę artykuły z drugiego nurtu, czyli „nowoczesności”. Tu znajduje się gros artykułów poświęconych telewizji, reklamie i nowym mediom ${ }^{36}$. Swego rodzaju

${ }^{34}$ K. Bulewicz, Szczęśliwe, kolorowe dzieciństwo...

${ }^{35}$ B. Szczupał, Rodzina ksztaltuje osobowość...

${ }^{36}$ U. Parnicka, Telewizja w życiu dziecka, EiD, grudzień 1994, http://www.eid.edu.pl/archiwum/1994,24/grudzien,34/; M. Sokołowski, Telewizja wróg czy sojusznik wychowania?, EiD, maj 1994, http://www.eid.edu.pl/archiwum/1994,24/maj,29/; M. Lewandowska, Wyzwania reklamy. Czy twoje dziecko ma już komputer?; I. Wolny, Reklama w odbiorze najmłodszych uczniów, EiD, kwiecień 1995, http://www.eid.edu.pl/archiwum/1995,93/kwiecien,108/; R. Wojdan-Jaskulska, Casus włoski; G. Wiergowski, Ekranowe wzorce do naśladowania; M. Braun-Gałkowska, 
ciekawostką, a właściwe anachronizmem, znakiem szybkiego postępu technologicznego, jest fakt zaliczenia do „nowych mediów” odchodzącego dziś już w zapomnienie wideo $^{37}$. Należy jednak mieć na uwadze, że nie samo wprowadzenie projekcji filmowych w czasie lekcji, ale ich dostępność i nieskomplikowana technika wyświetlania były powodem zachwytu nauczycieli korzystających z ich dobrodziejstwa i opisujących sposoby wzbogacania zajęć lekcyjnych dzięki takim możliwościom technicznym.

Z drugiej strony właśnie owa powszechna dostępność znanych dotąd mediów, takich jak np. film, telewizja czy wideo, stała się powodem niepokoju wielu nauczycieli, badaczy i edukatorów. Jak się dziś okazuje - obaw jak najbardziej uzasadnionych. Co ciekawe, większość tekstów wyrażających ów niepokój i prezentujących potwierdzające go badania powstała w pierwszej połowie lat dziewięćdziesiątych, głównie w okresie 1994-1995, później, tj. od roku $1996 \mathrm{i} \mathrm{w}$ latach następnych uwaga autorów koncentruje się na rozwijających się dynamicznie mediach interaktywnych, takich jak komputer i internet. Wątpliwości dotyczyły głównie gier komputerowych i wizji życia poddanego komputeryzacji. Opisane są jednak także pozytywne aspekty szybkiego postępu technologicznego i wykorzystania go do rozwijania misji edukacyjnej.

Czas powstania większości artykułów zaliczonych do nurtu ,nowoczesności”, czyli lata dziewięćdziesiąte w Polsce, to okres gwałtownych zmian, ścierania się ,nowego" ze „starym”, wypracowywania metod radzenia sobie z szybko następującymi zmianami, głównie rodzącą się wówczas wszechobecnością mediów, szczególnie telewizji. Stąd też nie powinno dziwić, że to właśnie jej poświęconych zostało najwięcej artykułów. Oprócz opisu negatywnego wpływu telewizji na rozwój dziecka pojawiły się także próby wskazania jej walorów edukacyjnych $^{38}$. Wiesław Sikorski, badając preferencje odbiorcze najmłodszych i zestawiając je z potencjałem edukacyjnym telewizji, doszedł do następujących konkluzji:

Telewizyjne dzieci, EiD, czerwiec 1995, http://www.eid.edu.pl/archiwum/1995,93/czerwiec,110/; M. Braun-Gałkowska, Reklama telewizyjna a dzieci (cz. 1), A. Żywczok, Wizja komputeryzacji życia, EiD, maj 1997, http://www.eid.edu.pl/archiwum/1997,95/maj,129/; M. Braun-Gałkowska, Reklama telewizyjna a dzieci (cz. 2), EiD, czerwiec 1997, http://www.eid.edu.pl/archiwum/1997,95/czerwiec,130/; L. Strumska-Białko, N. Pęcherzewska-Kaczmarek, Media a wychowanie, EiD, wrzesień 1997, http://www.eid.edu.pl/archiwum/1997,95/wrzesien,131/; M. Braun-Gałkowska, Gry komputerowe a psychika dziecka, EiD, listopad 1997, http://www.eid.edu.pl/ archiwum/1997,95/listopad,133/; W. Sikorski, Funkcje wychowawcze telewizji, EiD, kwiecień 1999, http://www.eid.edu.pl/archiwum/1999,97/kwiecien,148/; A. Porczak, Sztuka interaktywna w edukacji, EiD, maj 1999, http://www.eid.edu.pl/archiwum/1999,97/maj,149/.

${ }^{37}$ M. Sokołowski, Wideo interaktywne-nowa technologia nauczania, EiD, styczeń 1994, http://www.eid.edu.pl/archiwum/1994,24/styczen,25/; J. P. Sawiński, Wideo na lekcjach, EiD, czerwiec 1995, http://www.eid.edu.pl/archiwum/1995,93/czerwiec,110/.

${ }^{38}$ W. Sikorski, Funkcje wychowawcze telewizji... 
Aby więc telewizja mogła rzetelnie pełnić funkcje wychowawcze, należy zaczać zwracać większą uwagę na artystyczny kształt przekazu, a przede wszystkim rolę, jaką pełnią użyte w nim środki ekspresji pobudzające emocje. Chodzi tu zatem, by adaptując określone treści do warunków przekazu telewizyjnego, starać się odpowiednio łączyć podawane informacje z przeżyciem emocjonalnym, nadającym tym treściom emocjonalne konotacje i w sumie aktywizującym psychikę widza w czasie odbioru programu. Właśnie temu specyficznemu połączeniu treści (fabuły) i emocji zawdzięcza swoje powodzenie kino. Rzadko natomiast warunek ten spełnia program edukacyjny, w którym zazwyczaj dominuje treść, wprowadzająca zamęt w sferze emocjonalnej widza. Realizując programy oświatowe, trzeba pamiętać, iż przekaz wizualny o zabarwieniu emocjonalnym łatwiej komunikuje dane treści i tworzy pożądane nastawienie do podawanych w nim informacji (intencji nadawcy). A to w konsekwencji przybliża widzowi ów przekaz, dostarczając mu przeżyć, których doznawanie warunkuje efektywność wpływu wychowawczego. Uwzględnianie tych przesłanek jest ważne, gdyż telewizja nolens volens włączyła się $\mathrm{w}$ proces wychowania intencjonalnego w chwili, gdy zaczęła emitować programy z myślą o młodym widzu. Nie ulega wątpliwości, że telewizja może być wykorzystywana dla celów wychowawczych, aby jednak urealnić jej wpływ, jest konieczne branie pod uwagę przez autorów programów preferencji i oczekiwań młodego widza dotyczących treści i formy przekazu; aktualizowanie jego problemów, bieżące analizowanie ważnych zjawisk i zdarzeń bezpośrednio nurtujących dorastające pokolenia. Zasadne wydaje się również współdziałanie szkoły i telewizji, zarówno w sferze edukacyjnej, jak i wychowawczej oraz poszukiwanie jakichś form integrujących te obie instytucje w trosce o przyszłość dzieci i młodzieży ${ }^{39}$.

Spostrzeżenia i postulaty autora - jak się wydaje - także dziś niewiele tracą ze swej aktualności. Podobnie jak wnikliwe opracowania Marii Braun-Gałkowskiej, dotyczące wpływu reklamy na rozwój i zachowanie dzieci.

Właściwie każdy z tekstów odnoszących się do nowych zjawisk w życiu społecznym czy kulturowym jest cennym źródłem informacji, a jednocześnie wyrazem czujności autorów, ich daru obserwacji i twórczego podejścia wobec pojawiających się wyzwań. Niestety, ramy niniejszego wystąpienia, a także ogrom materiału nie pozwalają na precyzyjne omówienie każdego z artykułów. Skłaniają natomiast do wskazania najistotniejszych elementów i podjęcia próby krótkiego podsumowania rozważań poświęconych edukacji kulturalnej dziecka na łamach periodyku „Edukacja i Dialog” w latach dziewięćdziesiątych XX w.

$\mathrm{Z}$ pewnością nie zostały równomiernie rozłożone akcenty $\mathrm{w}$ przybliżaniu artykułów z pierwszego i drugiego nurtu. Była to jednak świadoma decyzja podyktowana przekonaniem, że tematy szans i zagrożeń płynących z rozwoju mediów są znakomicie opracowane, wciąż powstają nowe badania, media zaś stały się częścią naszej codzienności, ich oddziaływanie nie zmieniło się radykalnie. Natomiast przywołane propozycje i spostrzeżenia dotyczące ,tradycji” pozwalają lepiej uchwycić całość przemian zachodzących w edukacji kulturalnej dziecka. Uzmysławiają, jak olbrzymi postęp dokonał się $\mathrm{w}$ tej materii, szczególnie po wstąpieniu Polski do Unii Europejskiej i wykorzystaniu części obowiązujących tam wzorców. Zresztą, co pragnę na marginesie odnoto-

${ }^{39}$ Ibidem. 
wać, na łamach omawianego periodyku znalazły się również artykuły przybliżające standardy edukacyjne innych krajów ${ }^{40}$. Dopełniają one obraz całości przemian.

Lektura artykułów zawartych w „Edukacji i Dialogu” pozostawia - co może się wydać nieco zaskakujące - poczucie, że historia w pewnym sensie zatoczyła koło - postulaty stawiane na początku lat 90 . dziś pojawiły się ponownie - jak np. powrót muzyki do szkół czy wielokrotnie akcentowana potrzeba zwrócenia uwagi na edukację estetyczną i artystyczną dziecka, co dobitnie podkreślili uczestnicy niedawno zakończonego Kongresu Kultury Polskiej. Pozostaje zatem mieć nadzieję, że uda się choćby w części zrealizować owe postulaty i wyciągnąć wnioski z tego, co dotąd zostało zrobione.

${ }^{40}$ Zob. Z. Dominikowski, Szkoła francuska $w$ zbliżeniu, EiD, marzec 1995, http://www.eid. edu.pl/archiwum/1995,93/marzec,107/; B. Wiśniewska, System edukacji niepublicznej w Szwajcarii, EiD, styczeń 1998, http://www.eid.edu.pl/archiwum/1998,96/styczen,135/; B. Śliwerski, Jak Czesi zmieniaja szkotę?, EiD, wrzesień 1998, http://www.eid.edu.pl/archiwum/1998,96/wrzesien,141/; L. Kudła, Szkolnictwo niepubliczne w Danii, EiD, grudzień 1998, http://www.eid. edu.pl/archiwum/1998,96/grudzien,144/. 